\title{
Students' perceptions on distance education: A multinational study
}

\author{
Patricia Fidalgo ${ }^{1 *}$, Joan Thormann ${ }^{2}$, Oleksandr Kulyk ${ }^{3}$ and José Alberto Lencastre ${ }^{4}$
}

\author{
* Correspondence: pfidalgo@ecae. \\ ac.ae \\ ${ }^{1}$ Curriculum and Instruction \\ Division, Emirates College for \\ Advanced Education, Abu Dhabi, \\ United Arab Emirates \\ Full list of author information is \\ available at the end of the article
}

\begin{abstract}
Many universities offer Distance Education (DE) courses and programs to address the diverse educational needs of students and to stay current with advancing technology. Some Institutions of Higher Education (IHE) that do not offer DE find it difficult to navigate through the steps that are needed to provide such courses and programs. Investigating learners' perceptions, attitudes and willingness to try DE can provide guidance and recommendations for IHEs that are considering expanding use of DE formats. A survey was distributed to undergraduate students in Portugal, UAE and Ukraine. The results of this pilot study showed that in all three countries, students' major concerns about such programs were time management, motivation, and English language skills. Although students were somewhat apprehensive many indicated they were interested in taking DE courses. Six recommendations informed by interpretation of students' responses and the literature, are offered to assist institutions who want to offer DE as part of their educational strategy.

Keywords: Distance education, Multinational study, Perceptions of distance education, Undergraduate students
\end{abstract}

\section{Introduction}

The World Wide Web has made information access and distribution of educational content available to a large fraction of the world's population and helped to move Distance Education (DE) to the digital era. DE has become increasingly common in many universities worldwide (Allen \& Seaman, 2017). Nonetheless, there are still many universities that do not provide this opportunity because it is not part of their institutional culture. As DE becomes more prevalent, countries and Institutions of Higher Education (IHE) that do not provide DE courses will need to look at this option to retain and expand their student population. (Keegan, 1994; Nakamura, 2017).

In order to develop such programs, it is useful to determine if students are receptive to taking such online courses and are prepared to do so. This study addresses students' perceptions and their interest in DE. In addition, it provides a comparative analysis across three countries whose IHEs do not have extensive offerings in DE. The results of this research provide some strategies to encourage and support students to take DE courses.

(c) The Author(s). 2020 Open Access This article is licensed under a Creative Commons Attribution 4.0 International License, which permits use, sharing, adaptation, distribution and reproduction in any medium or format, as long as you give appropriate credit to the original author(s) and the source, provide a link to the Creative Commons licence, and indicate if changes were made. The images or other third party material in this article are included in the article's Creative Commons licence, unless indicated otherwise in a credit line to the material. If material is not included in the article's Creative Commons licence and your intended use is not permitted by statutory regulation or exceeds the permitted use, you will need to obtain permission directly from the copyright holder. To view a copy of this licence, visit http://creativecommons.org/licenses/by/4.0/. 


\section{Literature review}

A seminal article by Keegan (1980) presents key aspects of DE. Some of the elements are: physical separation of teacher and learner, learning occurs in the context of an educational institution, technical media are used, teacher and learner communicate, face to face meetings are possible, and an industrial model of providing education is used. More recently varying definitions of DE seem to be based on the perspective of various educators and to reflect the educational culture of each country and IHE. However, some common descriptors seem to be accepted by most stakeholders in the field. Distance education is an educational experience where instructors and learners are separated in time and space (Keegan, 2002) which means it can happen away from an academic institution and can lead to a degree or credential (Gunawardena, McIsaac, \& Jonassen, 2008).

Although there are different types of DE, this research focuses on online learning. The following types of online learning will be investigated: synchronous, asynchronous, blended, massive online open courses (MOOC), and open schedule online courses. In synchronous instruction, teachers and learners meet (usually online) for a session at a predetermined time. According to Watts (2016) live streaming video and/or audio are used for synchronous interaction. Although videoconferencing allows participants to see each other this is not considered a face-to-face interaction because of the physical separation (Keegan, 1980).

Asynchronous instruction means that teachers and learners do not have synchronous sessions and that students have access to course content through the Internet at any time they want or need. Communication among the participants occurs mainly through email and online forums and is typically moderated by the instructor (Watts, 2016). According to Garrison (2000) "Asynchronous collaborative learning may well be the defining technology of the postindustrial era of distance education." (p.12) Yet another type of DE is blended learning (BL). Garrison and Kanuka (2004) define BL as combining face-to-face classroom time with online learning experiences. Although it is not clear as to how much time is allocated to online in the blended model "the real test of blended learning is the effective integration of the two main components (face-to-face and Internet technology) such that we are not just adding on to the existing dominant approach or method." (p.97) In the BL format different teaching strategies and instructional technology can be used to help individuals who have different learning styles, needs and interests (Tseng \& Walsh Jr., 2016).

Another type of DE is MOOCs (Massive Online Open Courses). This format was first introduced in 2006 and offers distributed open online courses that are available without cost to a very large number of participants (Cormier, McAuley, Siemens, \& Stewart, 2010). MOOCs origins can be traced to the Open Access Initiative in 2002 which advocates sharing knowledge freely through the Internet. By providing educational opportunities MOOCs can address the increasing demand for training and education (Zawacki-Richter \& Naidu, 2016). Finally, in open schedule online courses students work asynchronously with all the materials being provided digitally. Although there are deadlines for submitting assignments, students working at their own pace have some independence as to when they do their coursework (Campus Explorer, 2019).

There are advantages and disadvantages in taking DE courses. Some of the advantages are self-paced study, time and space flexibility, time saving (no commute between 
home and school) and the fact that a distance learning course often costs less. Disadvantages include a sense of isolation, the struggle with staying motivated, lack of faceto-face interaction, difficulty in getting immediate feedback, the need for constant and reliable access to technology, and occasionally some difficulty with accreditation (De Paepe, Zhu, \& Depryck, 2018; Lei \& Gupta, 2010; Venter, 2003; Zuhairi, Wahyono, \& Suratinah, 2006).

Most of the literature concerning student perception of DE courses, both blended and entirely online, involves students who have enrolled in online courses. Some articles address comparisons of perceptions between face-to-face and online students regarding DE (Daniels \& Feather, 2002; Dobbs, del Carmen, \& Waid-Lindberg, 2017; Hannay \& Newvine, 2006; Lanier, 2006). Additional studies address adult and undergraduate students and cover many aspects of the online experience (Dobbs et al., 2017; Horspool \& Lange, 2012; Seok, DaCosta, Kinsell, \& Tung, 2010b, a). However, little, if any research has been conducted that only addresses perceptions of students who live in countries in which few IHEs offer online courses.

In a study comparing online and face-to-face learning, Horspool and Lange (2012) found that students chose to take online courses to avoid travel time to class and scheduling problems. A majority of both face-to-face and online students did not experience technological issues. Both groups also found that communication with the instructor was adequate. Online students indicated that instructor response time to questions was prompt. By contrast online students perceived peer communication as occurring much less often. Course satisfaction was comparable for both formats (Horspool \& Lange, 2012). Responses to another survey concerning online and traditional course formats found that students' reasons for taking online courses included flexibility to accommodate work and family schedules, the ability to avoid commuting to the university and more online courses being available to them (Dobbs et al., 2017). Both online and traditional students agreed that traditional courses were easier, and they learned more in that format. They also concurred that online courses required more effort. Experienced online students indicated that the quality of their courses was good while traditional students who had never taken an online course felt that the quality of online courses was lower.

There is additional research that focuses on students including those enrolled in community colleges, MOOCs, blended learning as well as adult learners. Community college students' and instructors' perceptions of effectiveness of online courses were compared by Seok et al. (2010b, a). The researchers focused on pedagogical characteristics (management, Universal Design for Learning, interaction, teaching design and content) and technical features (interface, navigation and support). In addition, responses were examined based on various aspects of the subjects' demographics. Two surveys with 99 items were distributed electronically. One survey was for instructors and the other for students. In general, instructors and students indicated that teaching and learning online was effective. Female students responded more positively to most questions concerning effectiveness, and instructors also found it more positive (Seok et al., 2010b, a).

Students who enrolled in a MOOC were motivated to take other courses in this format based on their perception that it was useful for achieving their goals. In addition, their motivation was high if the course was posted on a platform that was easy to use 
(Aharony \& Bar-Ilan, 2016). This study also found that as students proceeded through the course, they gained confidence.

Blended learning was examined by Kurt and Yildirim (2018) to determine student satisfaction and what they considered to be important features of the blended format. The results indicated that the Turkish students who participated, almost unanimously felt that BL was beneficial and that their own role and the instructors' role was central to their satisfaction. The authors stated, "the prominent components in the process have been identified as face-to-face lessons, the features of online course materials, LMS used, design-specific activities, process-based measurement and evaluation, student-student interaction and out-of-class sharing respectively." (p. 439) DE has a growth potential and offers the opportunity to reach many people (Fidalgo, 2012), hence it can be used as a technique for mass education (Perraton, 2008). According to Perraton (2008) DE can be adapted to the needs of current and previous generations who did not complete their education. DE can also reach individuals who live in remote locations and do not have the means to attend school.

\section{Methodology}

\section{Study goals}

The goal of this pilot study is to examine what undergraduate students' perceptions are concerning DE and their willingness to enroll in this type of course. This study focuses on three countries that do not offer extensive DE accredited programs. By comparing three countries with similar DE profiles, commonalties and differences that are relevant and useful can be found. When the IHEs from these countries decide or have the conditions to move towards DE, the results of this study may help them adapt this format to their particular context and students' needs. Results may also help IHEs plan their strategy for offering online courses to current and future students and attract prospective students who otherwise would not be able to enroll in the face-to-face courses that are available.

\section{Research questions}

1. Have undergraduate students taken an online course previously?

2. What are undergraduate students' perceptions of distance education?

3. What are the reasons for undergraduate students to enroll/not enroll is distance education courses?

4. What preparation do undergraduate students feel they need to have before taking distance education courses?

5. What is the undergraduate students' receptivity towards enrolling in distance education courses?

6. What types of distance education would undergraduate students be interested in taking?

\section{Setting}

This research was conducted at IHEs in three countries (Portugal, Ukraine and UAE). A description of each country's sociodemographic and technological use provides a context for this study. 
Portugal, a country located at the western end of the European continent, has a resident population of just over 10 million people (Instituto Nacional de Estatistica, 2019). Data collected by Instituto Nacional de Estatistica in 2019 indicated that almost 81\% of households in Portugal had Internet access at home. According to the Portuguese National Statistical Institute (2019), the rate of Internet use by the adult population is about $76 \%$. Among this population, people who attend or have completed secondary and higher education have a higher percentage of Internet use (98\%) (Instituto Nacional de Estatistica, 2019).

The most used devices to access the Internet are smartphones and laptops. Regarding computer tasks, the most frequent ones are copying and moving files and folders and transferring files from the computer to other devices (PORDATA - Base de Dados Portugal Contemporâneo, 2017).

Among Internet users, $80 \%$ use social networks, which is a higher percentage than the European Union (EU) average. Mobile Internet access (outside the home and workplace and on portable devices) is $84 \%$ and maintains a strong growth trend (Instituto Nacional de Estatistica, 2019).

Ukraine is one of the post-soviet countries located in Eastern Europe and it strives to be integrated in economic and political structures of the EU. The current population of the country is 42 million. Despite the low incomes of many Ukrainians, modern technological devices are widespread among the population. The State Statistics Service of Ukraine (2019) reported that there were 26 million Internet subscribers in the country in the beginning of 2019. However, Ukrainians do not have a high level of digital literacy yet. According to the Digital Transformation Ministry of Ukraine (Communications Department of the Secretariat of the CMU, 2019), almost 38\% of Ukrainian people aged from 18 to 70 have poor skills in computer literacy and $15.1 \%$ of the citizens have no computer skills.

According to the survey conducted by the Digital Transformation Ministry of Ukraine (The Cabinet of Ministers of Ukraine, 2019) 27.5\% Ukrainian families have a tablet, and $30.6 \%$ have one smart phone, $26.4 \%$ have two smart phones, $16.5 \%$ have three smart phones and $10.8 \%$ have four and more smart phones. As for laptops, $42.7 \%$ Ukrainian families have a laptop and $45.6 \%$ have a desktop computer (The Cabinet of Ministers of Ukraine, 2019). The data from the ministry did not indicate if families have multiple devices, however the data shows that technological devices are widespread.

The United Arab Emirates (UAE) is a country located in the Persian Gulf that borders with Oman and Saudi Arabia. The UAE has a population of 9.77 million and is one of the richest countries in the world based on gross domestic product (GDP) per capita. The resident population consists of 11,5\% Emiratis and the remaining residents are expats from countries such as India, Pakistan, Philippines, Egypt and others (Global Media Insight, 2020).

Regarding technology use, $91 \%$ of the residents use mobile Internetand over $98 \%$ of the households have Internet access (Knoema, 2018). Mobile devices such as smartphones are used to access the Internet mainly at home or at work (Federal Competitiveness and Statistics Authority, 2017).

In 2017 the most frequent Internet activities were: sending/receiving emails (61\%), posting information or instant messaging (55\%), getting information about goods or services (45\%), reading or downloading online newspapers, magazines or electronic 
books (41\%) and telephoning over the Internet/VOIP (33\%). Downloading movies, images, music, watching TV or video, or listening to radio or music is also a frequent activity performed by $27 \%$ of the Internet users followed by Internet banking (25\%) and purchasing or ordering good and services (22\%) (Federal Competitiveness and Statistics Authority, 2017).

While these three countries were selected due to the location of the researchers and thus provided convenience samples, the three countries have a similar lack of DE offerings. Online surveys were emailed to students enrolled in a variety of undergraduate face-to-face courses during the fall semester of 2018. The students in Portugal and the UAE were enrolled in a teacher education program and the survey was emailed to two course sections in Portugal (73 students) and four course sections in the UAE (108 students). At the IHE in Ukraine, students were majoring in applied mathematics, philology, diagnostics, social work and philosophy, and surveys were emailed to 102 students who were enrolled in five course sections. In Portugal and Ukraine, the URL for the online survey was emailed by the instructor of all the course sections. In the UAE the instructor who emailed the URL for the survey taught two of the course sections. The students in the other two sections knew this instructor from taking courses with her previously. The students participating in this study were a convenience sample based on the disciplines taught by the researchers.

\section{Data collection}

An online survey with 10 closed questions about undergraduate students' perception and receptivity towards enrolling in DE courses was developed by the researchers. Ary, Jacobs, Sorensen, and Walker (2010) compared traditional methods (i.e. face-to-face, paper and pencil) with web-based surveys and found the latter to be are more effective for gathering data from many participants. The questions designed by the researchers were informed by their experience/practice as well as in-depth literature review. The survey was created to respond to the research questions that guided this study. Response choices to the multiplechoice questions were based on issues and concerns related to DE. Students' responses were collected towards the end of the first semester of the 2018/19 academic year.

The survey was developed to address research questions that assess undergraduate students' perceptions of DE and students' receptivity towards enrolling in DE courses (c.f. Appendix). The use of surveys allows researchers to "obtain information about thoughts, feelings, attitudes, beliefs, values, perceptions, personality and behavioral intentions of research participants." (Johnson \& Christensen, 2014, p. 192) The survey questions included multiple response formats: Likert scale, select more than one response and multiple choice. Surveys for Portugal were presented in Portuguese. In Ukraine the surveys were translated into Ukrainian. Since English is the language of instruction at the UAE institution, their survey was in English. The URL for the survey was emailed to students by their instructors and was available in an online Google Form. The survey took approximately 10 min to complete. The study consisted of a "self-selected" convenience sample.

\section{Data analysis}

Survey results were recorded in Google Forms and an Excel spreadsheet was used to collect students' responses. Descriptive statistics of the responses to the survey are 
presented in graphs and tables with percentages of responses displayed. The descriptive statistics provide summaries about the sample's answers to each of the questions as well as measures of variability (or spread) and central tendency.

\section{Research approval and data management}

The research proposal was submitted to the Research and Grants Committee and approved by the Institutional Review Board of the college in the UAE. No personal information (name, College ID number or any other type of information that allows the identification of students) was asked from the students in the surveys. The surveys were anonymous. Only the Principal Investigator (PI) had access to all the data collected. The data will be stored in the PI's password protected computer for 5 years.

\section{Results}

Fifty five of the 73 Portuguese students who received the survey responded and 98 of the $108 \mathrm{UAE}$ students responded. In the Ukraine 102 students were sent surveys and 70 responded. Below are participants' responses to questions concerning age, gender, as well as level of confidence using the computer and the Internet.

Students' age range was from 17 to 50 years old. Most students' age ranges were between 17 and 29 years. Survey responses indicated that $7 \%$ of the students in the UAE were male and $93 \%$ female, in the Ukraine $43 \%$ were male and $57 \%$ female and in Portugal $9 \%$ male, and $91 \%$ female.

Participants were asked about their level of confidence using a computer and the Internet. Results are presented in Table 1.

The use of participants from three countries allows the study of trends and to determine differences and/or similarities of perceptions about DE. Although the students were enrolled in courses in diverse content areas, they were all undergraduates, almost all under 30 years old, and most were confident using the computer and Internet. These demographic similarities provided a relatively cohesive group for this study while allowing a comparison across countries.

A range of questions were asked about students' attitudes towards and experience with DE. To determine the participants' experience with DE two questions were asked.

The data indicates that out of 223 students who responded to the survey, a total of 63 students have taken DE courses. Half of the Ukraine students, about one quarter of the UAE students and only $5 \%$ of students in the group from Portugal had taken DE courses (Fig. 1). As shown in Fig. 2, of the students who have had previous experience in DE, most Ukraine students have taken one or two online courses, most UAE students have taken one course and a few Portuguese students have taken one course.

Table 1 Student confidence level using a computer and the Internet

\begin{tabular}{llllll}
\hline Country & Not at all confident & Somewhat confident & Neutral/ Cannot judge & Confident & Extremely confident \\
& Percent & Percent & Percent & Percent & Percent \\
\hline Portugal & 0.00 & 7.27 & 20.00 & 54.55 & 18.18 \\
Ukraine & 0.00 & 2.86 & 5.71 & 32.86 & 58.57 \\
UAE & 3.16 & 7.37 & 26.32 & 25.26 & 37.89 \\
\hline
\end{tabular}




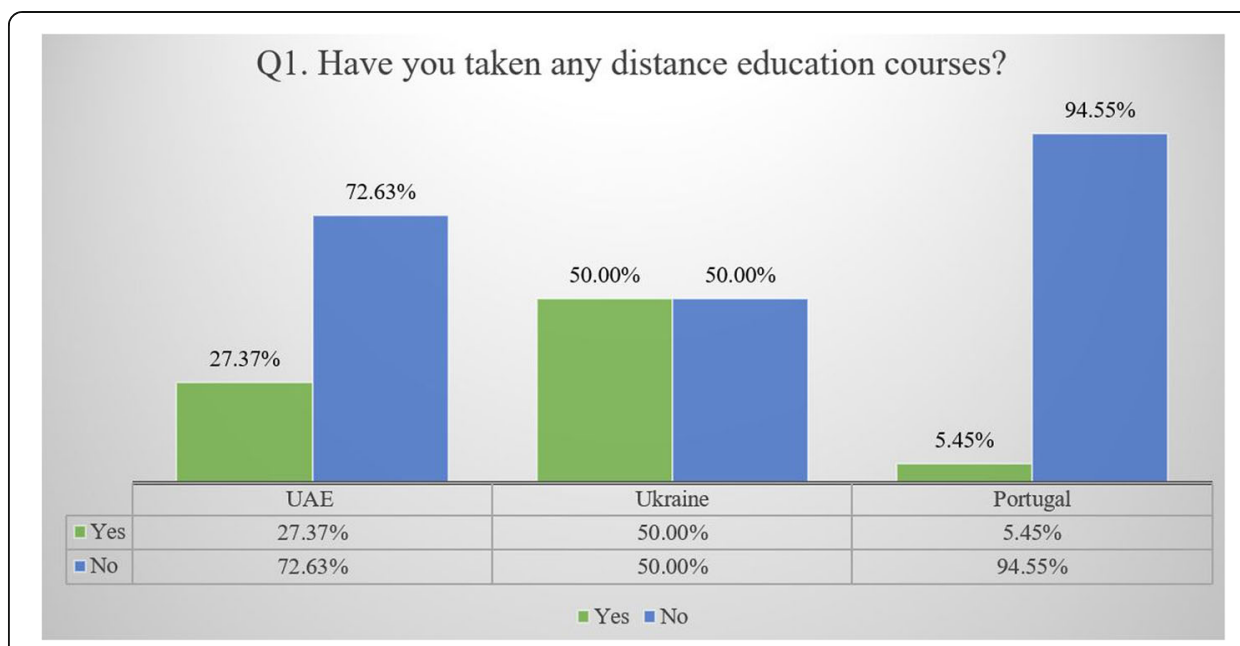

Fig. 1 Students that have taken distance education courses

More than half of Portuguese students, about two thirds of the Ukraine students and a little over one third of UAE students had a Very favorable or Favorable attitude towards DE. Approximately one third of Portuguese and Ukraine students were Neutral/Unable to judge their attitude. A little less than half of UAE students also indicated this. A small percentage of Portuguese, and one fifth of UAE students indicated their attitude was Very unfavorable or Unfavorable and no Ukraine students reported this (Table 2).

More than one third of Portuguese students shared that managing class and study time, saving time by choosing study location and working at their own pace were reasons to enroll in DE. About two thirds of the students from Ukraine reported that working at their own pace and managing their study time were reasons to enroll. A litthe more than half of these students reported that reasons for enrolling in DE included managing class time, saving time by selecting study location and not having to travel to school as well as having more options for courses or colleges to attend. Almost half of the UAE students had similar reasons for enrolling in a DE courses including managing class and study time, saving time by choosing study location and working at their own

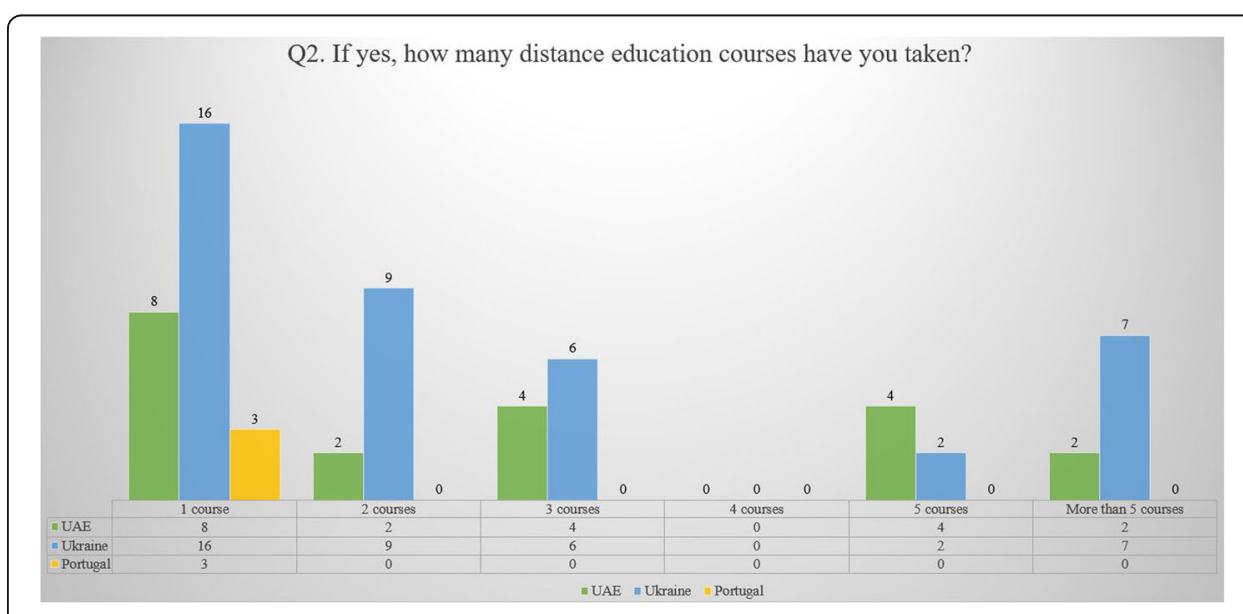

Fig. 2 Number of distance education courses taken 
Table 2 Attitudes toward distance education

\begin{tabular}{llllll}
\hline Country & $\begin{array}{l}\text { Very unfavorable } \\
\text { Percent }\end{array}$ & $\begin{array}{l}\text { Unfavorable } \\
\text { Percent }\end{array}$ & $\begin{array}{l}\text { Neutral/ Unable to judge } \\
\text { Percent }\end{array}$ & $\begin{array}{l}\text { Favorable } \\
\text { Percent }\end{array}$ & $\begin{array}{l}\text { Very favorable } \\
\text { Percent }\end{array}$ \\
\hline Portugal & 0.00 & 7.27 & 34.55 & 52.73 & 5.45 \\
Ukraine & 0.00 & 0.00 & 31.43 & 42.86 & 25.71 \\
UAE & 8.42 & 12.63 & 42.11 & 21.05 & 15.79 \\
\hline
\end{tabular}

pace. In addition, a little more than half of the UAE students also shared that having more options for courses or colleges to attend were reasons to enroll. The reasons that were selected the least by all three groups were that courses were less expensive and enrolling in a preferred program (Tables 3 and 4).

Students were given eleven options as to why they would not enroll in DE courses, which are displayed in Tables 5 and 6. Two reasons that were chosen most often were difficulty staying motivated and preferring face-to-face classes. A small number of Ukraine students reported this as a reason to not enroll in DE courses. Difficulty getting immediate feedback was also a concern for UAE students. Close to one third in the three groups indicated that difficulty contacting the instructor and interacting with peers as well as missing campus life are reasons for not enrolling. About one tenth of Portuguese, one fifth of Ukraine and one fifth of the UAE students reported difficulty getting accreditation as a reason for not enrolling. Not knowing enough about DE was indicated by one tenth of Portuguese, one fifth of Ukraine and one fifth of the UAE students. Only a small number of all the students indicated three categories that are frequently cited in the literature as preventing students from enrolling, these include access to technology, feeling of isolation and too great an expense.

Tables 7 and 8 show student responses to a question regarding the preparation they think they would need before enrolling in a DE course. A little over one tenth of the Portuguese students indicated that they needed better computer equipment, writing skills and a dedicated study space. About one quarter of these students reported they need better skills in the following areas: time management, computer and English language skills, as well as needing to have learning goals and objectives. Having a better Internet connection and the need to develop a study plan was shared by approximately one third of these students. Finally, the highest rated prerequisite for these Portuguese students was to be more motivated.

Few of the Ukraine students felt that they needed better computer equipment or skills, a dedicated study space or a better Internet connection at home. Their concerns focused on their behaviors as students since half or a little more than half felt they needed to be more motivated, have learning objectives and goals, a study plan and

Table 3 Reasons to enroll in distance education courses (More than one could be chosen)

\begin{tabular}{llllll}
\hline Country & Other & $\begin{array}{l}\text { It is less } \\
\text { expensive }\end{array}$ & $\begin{array}{l}\text { I can enroll in the programs that } \\
\text { I really want }\end{array}$ & $\begin{array}{l}\text { Percent have more options } \\
\text { when selecting courses } \\
\text { and/or a college } \\
\text { Percent }\end{array}$ & $\begin{array}{l}\text { I don't have to } \\
\text { travel to school }\end{array}$ \\
\hline Portugal & 1.82 & 5.45 & 9.09 & 12.73 & Percent \\
Ukraine & 0.00 & 20.00 & 32.86 & 51.43 & 20.00 \\
UAE & 2.11 & 21.05 & 27.37 & 29.47 & 51.43 \\
\hline
\end{tabular}


Table 4 Reasons to enroll in distance education courses (More than one could be chosen)

\begin{tabular}{lllll}
\hline Country & $\begin{array}{l}\text { I can work at } \\
\text { my own pace }\end{array}$ & $\begin{array}{l}\text { I can manage my } \\
\text { own study time }\end{array}$ & $\begin{array}{l}\text { I can save time by } \\
\text { studying from a } \\
\text { location I choose } \\
\text { Percent }\end{array}$ & $\begin{array}{l}\text { I can manage my } \\
\text { own class time }\end{array}$ \\
\hline Portugal & 36.36 & Percent & 38.18 & Percent \\
Ukraine & 67.14 & 64.29 & 54.29 & 45.45 \\
UAE & 47.37 & 48.42 & 48.42 & 55.71 \\
\hline
\end{tabular}

better management skills. About one third of these students also reported that they needed better English language skills.

The UAE students were less confident than the Ukraine students about computer skills and needing better equipment and a better Internet connection at home. Almost half of these UAE students reported their need for a study plan and motivation as their most pressing needs. Better management and English language skills were recorded by about one third of the students. One quarter of the UAE students felt they needed better writing skills and a dedicated study space.

Table 9 shows students' interest in enrolling in DE courses. Almost one quarter of the Ukraine students are Extremely interested in taking DE courses and almost half are Somewhat interested. This contrasts with the students from Portugal who indicated that only $5 \%$ are Extremely interested and almost a quarter Somewhat interested. The UAE students' interest in enrolling fell in between the students from the two other countries. One fifth to almost one third of all three groups were Neutral/Unable to judge. About one tenth of students from Ukraine reported Not being very interested or Not at all interested which contrasts with the Portuguese and UAE students whose numbers were about one half and one quarter respectively.

Tables 10 and 11 show the types of DE that the students were interested in trying. Portuguese students favored Open schedule courses, followed by Blended learning and Synchronous. Few of these students were interested in MOOCs and Asynchronous. More than half of the students from Ukraine were interested in MOOCs and Blended learning followed by Open schedule. About one third of these students were interested in Synchronous and Asynchronous. UAE students most popular formats were Open schedule and Blended learning followed by Synchronous and Asynchronous. There was little interest in MOOCs by the UAE students. Few Portuguese and Ukraine students indicated that they would not take a DE course, however, almost a quarter of the UAE students indicated this.

Table 5 Reasons to not enroll in distance education courses (More than one could be chosen)

\begin{tabular}{|c|c|c|c|c|c|c|}
\hline \multirow[t]{2}{*}{ Country } & $\begin{array}{l}\text { It is too } \\
\text { expensive }\end{array}$ & $\begin{array}{l}\text { I do not have } \\
\text { constant, reliable } \\
\text { access to } \\
\text { technology }\end{array}$ & $\begin{array}{l}\text { I would } \\
\text { feel very } \\
\text { isolated }\end{array}$ & $\begin{array}{l}\text { I would have } \\
\text { difficulty getting } \\
\text { accreditation for } \\
\text { the course }\end{array}$ & $\begin{array}{l}\text { I do not know } \\
\text { enough about } \\
\text { distance education } \\
\text { courses }\end{array}$ & $\begin{array}{l}\text { I would } \\
\text { miss } \\
\text { campus } \\
\text { life }\end{array}$ \\
\hline & Percent & Percent & Percent & Percent & Percent & Percent \\
\hline Portugal & 1.82 & 7.27 & 10.91 & 10.91 & 12.73 & 25.45 \\
\hline Ukraine & 0.00 & 2.86 & 8.57 & 27.14 & 21.43 & 28.57 \\
\hline UAE & 1.05 & 15.79 & 17.89 & 21.05 & 28.42 & 31.58 \\
\hline
\end{tabular}


Table 6 Reasons to not enroll in distance education courses (More than one could be chosen)

\begin{tabular}{llllll}
\hline Country & $\begin{array}{l}\text { I would have } \\
\text { difficulty contacting } \\
\text { the instructors }\end{array}$ & $\begin{array}{l}\text { I would have } \\
\text { difficulty } \\
\text { interacting } \\
\text { with peers }\end{array}$ & $\begin{array}{l}\text { It would be } \\
\text { difficult for me to } \\
\text { stay motivated }\end{array}$ & $\begin{array}{l}\text { I would have } \\
\text { difficulty getting } \\
\text { immediate } \\
\text { feedback }\end{array}$ & $\begin{array}{l}\text { I prefer face } \\
\text { to face to } \\
\text { face classes }\end{array}$ \\
\hline Portugal & Percent & Percent & Percent & Percent & Percent \\
Ukraine & 28.27 & 30.91 & 30.91 & 32.73 & 52.73 \\
UAE & 32.63 & 21.43 & 65.71 & 24.29 & 14.29 \\
\hline
\end{tabular}

\section{Discussion}

Data indicates close to a $100 \%$ of the UAE residents use the Internet at home or on their mobile devices (Knoema, 2018). By contrast a smaller percentage of individuals use the Internet in Portugal and the Ukraine (Infographics, 2019). Internet use in each country does not seem to greatly impact UAE students' opinions regarding DE.

Students' perceptions of DE vary across the participants from the three countries. Portuguese and Ukrainian students rated DE more favorably than UAE students. Half of the Ukrainian students have experience with DE which might account for their favorable attitude. In contrast, in Portugal only a very small percentage of the students had experience. However, this does not seem to have negatively influenced their attitude towards DE. The interest level and engagement with new technologies by Portuguese students may help explain the favorable perception the participants had toward DE. A study by Costa, Faria, and Neto (2018) found that $90 \%$ of Portuguese students use new technologies and $69 \%$ of them use new technologies more than an hour and a half a day. Based on three European studies, Diário de Noticias (2011) stated that Portuguese students "appear at the forefront of those who best master information and communication technologies (ICT)." (para.1) Another factor influencing respondents might be that currently, and for the first time, the Portuguese government has passed a law that will regulate DE in the country. This new law will open the possibility for other IHEs to provide DE courses that lead to a degree.

Ukrainian students reported a high level of confidence in operating technological devices. The reason for this may be, in part, because of state educational requirements. Since the end of the 1990s, all Ukrainian students in secondary schools have at least one computer course as a mandatory element of their curriculum. This course covers a wide range of issues, which vary from information society theory to applied aspects of computer usage. Among the seven learning goals of this course three address digital

Table 7 Preparation students feel they need before enrolling in distance education courses (More than one could be chosen)

\begin{tabular}{|c|c|c|c|c|c|}
\hline \multirow[t]{2}{*}{ Country } & $\begin{array}{l}\text { I would need } \\
\text { better computer } \\
\text { equipment }\end{array}$ & $\begin{array}{l}\text { I would need } \\
\text { better writing } \\
\text { skills }\end{array}$ & $\begin{array}{l}\text { I would need a } \\
\text { dedicated study } \\
\text { space }\end{array}$ & $\begin{array}{l}\text { I would need to } \\
\text { have learning } \\
\text { objectives and } \\
\text { goals }\end{array}$ & $\begin{array}{l}\text { I would need better } \\
\text { time management } \\
\text { skills }\end{array}$ \\
\hline & Percent & Percent & Percent & Percent & Percent \\
\hline Portugal & 12.73 & 14.55 & 14.55 & 25.45 & 25.45 \\
\hline Ukraine & 5.71 & 7.14 & 12.86 & 57.14 & 50.00 \\
\hline UAE & 16.84 & 25.26 & 25.26 & 27.37 & 32.63 \\
\hline
\end{tabular}


Table 8 Preparation students feel they need before enrolling in distance education courses (More than one could be chosen)

\begin{tabular}{llllll}
\hline Country & $\begin{array}{l}\text { I would need } \\
\text { better } \\
\text { computer skills } \\
\text { Percent }\end{array}$ & $\begin{array}{l}\text { I would need better } \\
\text { language skills } \\
\text { (mainly English) } \\
\text { Percent }\end{array}$ & $\begin{array}{l}\text { I would need a better } \\
\text { Internet connection } \\
\text { at home } \\
\text { Percent }\end{array}$ & $\begin{array}{l}\text { I would need to } \\
\text { develop a study } \\
\text { plan }\end{array}$ & $\begin{array}{l}\text { I would need } \\
\text { to be more } \\
\text { motivated }\end{array}$ \\
\hline Portugal & 27.27 & 27.27 & 30.91 & 34.55 & Percent \\
Ukraine & 5.71 & 35.71 & 8.57 & 50.00 & 38.18 \\
UAE & 35.79 & 36.84 & 38.95 & 44.21 & 45.57 \\
\hline
\end{tabular}

literacy (Ministry of Education and Science of Ukraine, 2017). Ukrainian students who responded to the survey have taken computer courses for at least 5 years.

In the UAE, most DE courses and programs are not accredited by the Ministry of Education (United Arab Emirates Ministry of Education, 2016), which may account for UAE students lack of experience and their inability to judge this type of instruction.

It is worth analyzing the reasons why students enrolled or would enroll in DE courses. The reasons for taking DE courses, such as time management issues, are supported by studies concerning self-regulation and higher retention rates (Bradley, Browne, \& Kelley, 2017; Peck, Stefaniak, \& Shah, 2018). Students' interest in having more control of their study time is also mentioned as one of the primary benefits of DE (Alahmari, 2017; Lei \& Gupta, 2010). Regarding the reasons for not enrolling in DE courses, participants from the three countries mentioned difficulty contacting instructors and peers. Also, more than half of the students in Portugal and the UAE indicated they preferred face-to-face classes. Most students have spent their entire academic lives in traditional classes where interaction and immediate feedback from instructors and peers are more common. These concerns may be why students perceive they would lose a familiar type of interaction and have to engage with classroom participants in a new and different way (Carver \& Kosloski Jr., 2015; Morris \& Clark, 2018; Robinson \& Hullinger, 2008; Summers, Waigandt, \& Whittaker, 2005). It should be noted that the Portuguese and UAE students were enrolled in teacher education programs and are training to be face-to-face teachers. They may not understand the potential of DE format and are not preparing or expecting to use DE in their professional careers.

Difficulty being motivated was another reason chosen by the participants of the three countries to not enroll in DE courses. The lack of experience in this type of educational format may help explain student lack of confidence with their ability to study and stay on task. This response contrasts with the reasons reported for enrolling in DE courses such as controlling their study time. On one hand, participants like the prospect of having the ability to manage their own time. On the other hand, they are concerned they may lack the discipline they need to be successful.

Table 9 Interest in enrolling in a distance education course

\begin{tabular}{llllll}
\hline Country & $\begin{array}{l}\text { Not at all } \\
\text { interested } \\
\text { Percent }\end{array}$ & $\begin{array}{l}\text { Not very } \\
\text { interested } \\
\text { Percent }\end{array}$ & $\begin{array}{l}\text { Neutral/ Unable } \\
\text { to judge } \\
\text { Percent }\end{array}$ & $\begin{array}{l}\text { Somewhat } \\
\text { interested } \\
\text { Percent }\end{array}$ & $\begin{array}{l}\text { Extremely } \\
\text { interested } \\
\text { Percent }\end{array}$ \\
\hline Portugal & 18.18 & 29.09 & 25.45 & 21.82 & 5.45 \\
Ukraine & 4.29 & 7.14 & 21.43 & 44.29 & 22.86 \\
UAE & 14.74 & 10.53 & 31.58 & 25.26 & 17.89 \\
\hline
\end{tabular}


Table 10 Types of distance education interested in trying (More than one could be chosen)

\begin{tabular}{llll}
\hline Country & $\begin{array}{l}\text { MOOC (Massive Online Open } \\
\text { Courses - a free course available } \\
\text { on the Internet to a very large } \\
\text { number of people) }\end{array}$ & $\begin{array}{l}\text { I would not take a distance course } \\
\text { Percent }\end{array}$ & $\begin{array}{l}\text { Asynchronous (Students and } \\
\text { instructor do not meet at the } \\
\text { same time online. All course } \\
\text { work is done online.) }\end{array}$ \\
\hline Portugal & 90.9 & 10.91 & Percent \\
Ukraine & 54.29 & 1.43 & 12.73 \\
UAE & 8.42 & 22.11 & 30.00 \\
\hline
\end{tabular}

Although the literature indicates that access to technology, isolation and expense are reasons frequently cited as preventing students from enrolling in DE courses (Lei \& Gupta, 2010; Venter, 2003; Zuhairi et al., 2006), these reasons were selected by a very small percentage of the participants of this study. Access and affordability of technology has rapidly increased over the last decade which may help explain this inconsistency. Students may understand that DE courses are now less expensive than traditional university courses (Piletic, 2018) and they do not cite this as a reason for not enrolling. Relatively few students indicated they would feel isolated. Since this generation is in constant communication using technology (Diário de Notícias, 2011) they may not associate DE learning with isolation. However, it is interesting to note that there was a greater concern for interacting with instructors and peers than isolation.

The Ukrainian students are the most receptive to enrolling in DE courses. This is consistent with their positive perception of this type of learning. In addition, the previous experience of half of the participants may influence their interest as well as encourage their peers' receptivity. UAE students do not have much experience and fewer than half are open to enrolling in DE courses. This may be due to their lack of experience and other concerns previously mentioned. Only one third of the Portuguese participants indicated their interest in enrolling in DE courses. This is in contrast with almost two thirds saying they had a favorable or very favorable attitude. The reasons for this inconsistency are not evident.

In terms of preparation needed to take DE courses, technical concerns were less of an issue for the participants of all three countries than skills and behaviors. Most participants' answers focused on student skills including computer, English language and time management. Behaviors such as developing a study plan, having learning goals and objectives and being more motivated were also mentioned. The perceived need for better English language skills was expressed by about one third of the participants, none of whom have English as their native language. English speaking countries have been dominant in DE making English the most commonly used language in online

Table 11 Types of distance education interested in trying (More than one could be chosen)

\begin{tabular}{llll}
\hline Country & $\begin{array}{l}\text { Synchronous (Students } \\
\text { and instructor meet at } \\
\text { the same time online) }\end{array}$ & $\begin{array}{l}\text { Blended learning (Some } \\
\text { classes are taken online } \\
\text { others face to face on } \\
\text { campus) }\end{array}$ & $\begin{array}{l}\text { Open schedule (Students study } \\
\text { on their own time schedule) }\end{array}$ \\
\hline Portugal & Percent & Percent & Percent \\
Ukraine & $35.45 \%$ & $29.09 \%$ & $61.82 \%$ \\
UAE & $30.00 \%$ & $52.86 \%$ & $45.71 \%$ \\
\hline
\end{tabular}


learning (Sadykova \& Dautermann, 2009). Regarding time management, half of the Ukrainian students expressed their need for improvement in contrast to approximately one third of the participants from the other countries. The difference among responses may be because the Ukrainian students are more self-reflective, or the others are more disciplined. Although both DE and face-to-face courses have deadlines for tasks and assessments, in the face-to-face courses, students meet in person with their instructors who may support and press them to do their work. Lack of in person contact may account for the participants feeling they need to improve these skills when taking DE courses (De Paepe et al., 2018). Students expressed concerns about lacking certain skills and having certain behaviors that would lead them to be reluctant to enroll in DE courses. The need for help and preparation are some of the concerns that participants reported. Perceived needs may account for the students' apprehensions regarding taking DE courses. To promote this type of instruction, IHEs could address students' concerns (Mahlangu, 2018).

Open schedule and blended learning courses were the two preferred formats stated by the participants. The reason that Open schedule is the most popular may be that it provides more freedom than other types of courses. Blended learning offers the familiar face-to-face instruction and some of the conveniences of DE which may be why participants are interested in this model.

Studies regarding the use of MOOCs in all three countries have been conducted indicating that researchers in these locations are aware that this course format is of potential interest to local students (Eppard \& Reddy, 2017; Gallacher, 2014; Gonçalves, Chumbo, Torres, \& Gonçalves, 2016; Sharov, Liapunova, \& Sharova, 2019; Strutynska \& Umryk, 2016). Ukrainian students selected MOOCs much more than students in the other countries. The reason for this may be that these students are more knowledgeable about MOOCs, because this type of course is usually at no cost and/or offered by prestigious IHEs (Cormier et al., 2010). However, this study did not ask why students were interested in MOOCs or other types of DE courses.

\section{Limitations and future research}

While this study offers useful information regarding undergraduate students' perception and receptivity in taking DE courses, it has limited generalizability because of the size of the sample and the type of statistical analysis performed. Participants from two of the countries were enrolled in teacher education programs and were primarily female, thus future studies would benefit from including more students in diverse programs and a more equitable gender distribution.

Since many IHEs also offer programs for graduate students it would be useful to survey these students about their opinion and availability to enroll in DE courses. This would provide additional information for IHEs that are interested in developing DE programs.

There were some inconsistencies in the students' responses such as Portuguese students' interest in enrolling in DE courses not matching their favorable/ very favorable attitude towards DE. It would be helpful to conduct future research regarding this and other inconsistencies.

A study is currently being planned to collect data that will provide a larger and more diverse sample and include additional IHEs. This future research will potentially increase the available knowledge on how to provide DE for a greater number of students. 


\section{Conclusion and recommendations}

Further development of DE courses and programs at IHEs in countries such as Portugal, UAE and Ukraine have good prospects. The students' primary concerns regarding taking DE courses were similar among the three countries. These concerns included time management, motivation, and English language skills. However, this did not totally diminish participants interest in taking online courses especially for the Ukrainian students.

Based on this research, there are some obstacles that can be addressed to support the expansion of DE in the three countries that were studied and in other countries. The following recommendations may assist IHEs in promoting DE.

\section{Recommendations for preparation within IHEs}

IHEs can take proactive steps to prepare DE offerings, however, a one-size fit all model may not be appropriate for all countries and IHEs. Each institution needs to develop their own plan that meets the needs of their students and faculty. Data from this pilot study and the literature (Elbaum, McIntyre, \& Smith, 2002; Hashim \& Tasir, 2014; Hux et al., 2018) suggest that following steps might be taken:

- Assess readiness to take DE courses through a survey and have students speak with counselors.

- Provide pre-DE courses to build skills and behaviors based on students' concerns.

- Train instructors to develop and deliver DE courses that help to overcome obstacles such as motivation and time management.

- Offer courses in a blended learning format to familiarize students with online learning which may provide a transitional model.

\section{Recommendations for IHE outreach}

This study shows that there is some student interest in enrolling in online courses. It is not sufficient for IHEs to make changes internally within their own institution. IHEs need to develop external strategies and actions that help advance the development of DE:

- Promote DE in social media to target potential students and encourage them to take courses.

- Urge government agencies to accredit DE courses and programs.

This pilot study provides some background information that may help IHEs to offer DE courses. Additional research about students' preferences and needs regarding DE should be conducted. The sample size, IHEs included and participating countries could be expanded in order to gain a greater understanding.

Different cultural characteristics need to be taken into account in the development of online courses and programs. DE is being increasingly included by IHEs all around the world. To stay current, universities will need to find ways to offer DE to their current and prospective students. 


\section{Appendix}

Online Survey Questions

1. If the students have taken any distance education courses previously and if yes, how many;

2. What are the students' perceptions of distance education;

3. What are the reasons students would enroll in distance education courses;

4. What are the reasons students would not enroll in a distance education course;

5. What preparation do students feel they need before taking distance education courses;

6. What is the level of students' interest towards enrolling in distance education courses;

7. What types of distance education would students be interested in trying;

8. What is the students' age;

9. What is the students' gender;

10. How confident do students feel using a computer and the Internet.

Acknowledgements

Not applicable.

Authors' contributions

Patricia Fidalgo: design of the work, data collection, analysis, interpretation of data, and draft of the work. Joan Thormann: design of the work, analysis, interpretation of data, and draft of the work. Oleksandr Kulyk: data collection, interpretation of data, and draft of the work. José Alberto Lencastre: data collection. The author(s) read and approved the final manuscript.

Funding

This research was not funded.

Availability of data and materials

The datasets generated and/or analysed during the current study are not publicly available due privacy reasons but are available from the corresponding author on reasonable request.

\section{Competing interests}

The authors declare that they have no competing interests.

\section{Author details}

${ }_{1}^{1}$ Curriculum and Instruction Division, Emirates College for Advanced Education, Abu Dhabi, United Arab Emirates. ${ }^{2}$ Educational Technology Division, Lesley University, Cambridge, MA, USA. ${ }^{3}$ Philosophy Department, Oles Honchar Dnipro National University, Dnipropetrovs'ka oblast, Ukraine. ${ }^{4}$ Department of Curricular Studies and Educational Technology, University of Minho, Braga, Portugal.

Received: 11 December 2019 Accepted: 18 March 2020

Published online: 20 May 2020

References

Aharony, N., \& Bar-llan, J. (2016). Students' perceptions on MOOCs: An exploratory study. Interdisciplinary Journal of e-Skills and Life Long Learning, 12, 145-162 Retrieved from http://www.jjello.org/Volume12/IJELLv12p145-162Aharony2631.pdf.

Alahmari, A. (2017). The state of distance education in Saudi Arabia. Quarterly Review of Distance Education, 18(2), 91-98.

Allen, I. E., \& Seaman, J. (2017). Digital Learning Compass: Distance Education Enrollment Report 2017. Retrieved from https:// files.eric.ed.gov/fulltext/ED580868.pdf

Ary, D., Jacobs, L. C., Sorensen, C. K., \& Walker, D. A. (2010). Introduction to research in education. Belmont: Wadsworth.

Bradley, R., Browne, B., \& Kelley, H. (2017). Examining the influence of self-efficacy and self-regulation in online learning. College Student Journal, 51(4), 518-530.

Campus Explorer. (2019). Different Types of Distance Learning. Retrieved from: https://www.campusexplorer.com/collegeadvice-tips/7021E31E/Different-Types-of-Distance-Learning/

Carver, D. L., \& Kosloski Jr., M. F. (2015). Analysis of student perceptions of the psychosocial learning environment in online and face-to-face career and technical education courses. Quarterly Review of Distance Education, 16(4), 7-21 Retrieved from https://digitalcommons.odu.edu/cgi/viewcontent.cgi?article=1056\&context=stemps_etds.

Communications Department of the Secretariat of the CMU. (2019). Oleksiy Honcharuk: National Digital Literacy Platform "Diia: Digital Education" will be launched on January 21. Retrieved February 24, 2020, from Government Portal website: https://www.kmu.gov.ua/en/news/oleksij-goncharuk-nacionalna-osvitnya-platforma-z-cifrovoyi-gramotnosti-diya-cifrovaosvita-startuye-vzhe-21-sichnya 
Cormier, D., McAuley, A., Siemens, G., \& Stewart, B. (2010, December 8). What is a MOOC? [Video file]. Retrieved from http:// www.youtube.com/watch?v=eW3gMGqcZQc

Costa, I. P. E., Faria, H. d. C., \& Neto, A. S. (2018). Habits of use of new technologies in children and young people. Gazeta Médica, 5(4) Retrieved from doi: 10.29315/gm.v5i4.214.

Daniels, C., \& Feather, S. R. (2002). Student perceptions of online learning: A comparison of two different populations. In Proceedings of the Conference on Information Systems Applied Research, USA Retrieved from https://docplayer.net/729469Student-perceptions-of-online-learning-a-comparison-of-two-different-populations.html.

De Paepe, L., Zhu, C., \& Depryck, K. (2018). Online Dutch L2 learning in adult education: Educators' and providers' viewpoints on needs, advantages and disadvantages. Open Learning, 33(1), 18-33. https://doi.org/10.1080/02680513.2017.1414586.

Diário de Notícias (2011, August 10). Jovens portugueses são líderes das novas tecnologias. Diário de Notícias [Online]. Retrieved from https://www.dn.pt/ciencia/tecnologia/interior/jovens-portugueses-sao-lideres-das-novas-tecnologias-194 9445.html

Dobbs, R., del Carmen, A., \& Waid-Lindberg, C. (2017). Students' perceptions of online courses: The effect of online course experience. The Quarterly Review of Distance Education, 18(1), 98-109 Retrieved from https://eric.ed.gov/?id=EJ864039.

Elbaum, B., McIntyre, C., \& Smith, A. (2002). Essential elements: Prepare, design, and teach your online course. Madison: Atwood Publishing.

Eppard, J., \& Reddy, P. (2017). Localizing content for an XMOOC in the UAE. In 14th international conference on cognition and exploratory learning in the digital age, CELDA 2017, (pp. 329-330).

Fidalgo, P. (2012). Learning Networks and Moodle Use in Online Courses: A Social Network Analysis Study. Universidade Nova de Lisboa.

Federal Competitiveness and Statistics Authority. (2017). Information and communications technology (ICT) - UAE data. Retrieved from FCSA UAE Numbers Portal website: https://uaenumbers.fcsa.gov.ae/UAEICT2018/information-andcommunications-technology-ict

Gallacher, D. (2014). Navigating the impending MOOC storm in middle eastern higher education. In 8th International Technology, Education and Development Conference, 6522-6531. Valencia: IATED.

Garrison, D. R. (2000). Theoretical challenges for distance education in the 21st century: A shift from structural to transactional issues. The International Review of Research in Open and Distance Learning, 1(1), 1-17 Retrieved from http://www.irrodl. org/index.php/irrodl/article/viewArticle/2.

Garrison, D. R., \& Kanuka, H. (2004). Blended learning: Uncovering its transformative potential in higher education. The Inernet and Higher Education, 7(2), 95-105. https://doi.org/10.1016/j.iheduc.2004.02.001.

Global Media Insight. (2020). United Arab Emirates Population Statistics (2020). Retrieved January 28, 2020, from https:/www. globalmediainsight.com/blog/uae-population-statistics/

Gonçalves, V., Chumbo, I., Torres, E., \& Gonçalves, B. (2016). Teacher education through Mooc: A case study. In ICERI2016 Proceedings, (pp. 8350-8358). https://doi.org/10.21125/iceri.2016.090.

Gunawardena, C., Mclsaac, M., \& Jonassen, D. (2008). Distance education. In D. Jonassen (Ed.), Handbook of research on educational communications and technology: Project of the Association for Educational Communications and Technology (AECT series), (pp. 355-396). New York: Lawrence Erlbaum Associates Inc. Retrieved from http://ocw.metu.edu.tr/file. php/118/Week10/Gunawardena-Mclsaac-distance-ed.pdf.

Hannay, M., \& Newvine, T. (2006). Perceptions of distance learning: A comparison of online and traditional learning. MERLOT Journal of Online Learning and Teaching, 2(1), 1-11 Retrieved from http://jolt.merlot.org/documents/MS05011.pdf.

Hashim, H., \& Tasir, Z. (2014). E-learning readiness: A literature review. In Proceedings - 2014 international conference on teaching and learning in computing and engineering, LATICE 2014, (pp. 267-271). https://doi.org/10.1109/LaTiCE.2014.58.

Horspool, A., \& Lange, C. (2012). Applying the scholarship of teaching and learning: Student perceptions, behaviours and success online and face-to-face. Assessment \& Evaluation in Higher Education, 17(1), 73-88 Retrieved from https://srhe. tandfonline.com/doi/abs/10.1080/02602938.2010.496532\#.XX-XPigzZPY.

Hux, A., Nichols, C., Nichols, J., Henley, J., McBride, J., Bradley, M. J., \& Hux, R. (2018). Orientation, preparation, and support of online adjunct Faculty for Online Course Delivery: Developing, Conducting and financing a weekend. In Society for Information Technology \& Teacher Education International Conference Retrieved from https:/www.learntechlib.org/p/182728/.

Infographics, S. M. M. (2019). UAE internet statistics 2019 (Infographics). Retrieved February 25, 2020, from GMl blogger website: https://www.globalmediainsight.com/blog/uae-internet-and-social-media-usage-statistics/

Instituto Nacional de Estatistica. (2019). 80\% dos utilizadores de internet participam em redes sociais. Retrieved January 19, 2020, from Sociedade da Informação e do Conhecimento website: https://www.ine.pt/xportal/xmain?xpid=INE\&xpgid= ine_pesquisa\&frm_accao=PESQUISAR\&frm_show_page_num=1\&frm_modo_pesquisa=PESQUISA_SIMPLES\&frm_texto= Inquérito+à+utilização+de+tecnologias+de+informação+e+comunicação+pelas+famílias\&frm_modo_texto=MODO_ TEXTO_AL

Johnson, R. B., \& Christensen, L. (2014). Educational research: Quantitative, qualitative and mixed approaches. Thousand Oaks: Sage.

Keegan, D. (1994). The competitive advantages of distance teaching universities. Open Learning: The Journal of Open, Distance and e-Learning, 9(2), 36-39. https://doi.org/10.1080/0268051940090206.

Keegan, D. (2002). The future of learning: From eLearning to mLearning. Hagen: Zentrales Institut fur Fern Universitat Retrieved from https://www.academia.edu/3442041/The_future_of_learning_From_elearning_to_mLearning.

Keegan, D. J. (1980). On the Nature of Distance Education. ZIFF Papiere 33. Retrieved from https://eric.ed.gov/?q=Desmond+ keegan\&id=ED311890

Knoema. (2018). No Emirados Árabes - Share of households with InternetTitle. Retrieved February 24, 2020, from Atlas mundial de dados website: https:/pt.knoema.com/atlas/Emirados-Árabes/topics/Telecomunicação/Usuários-de-internet/ Share-of-households-with-Internet

Kurt, S. C., \& Yildirim, B. (2018). The students' perceptions on blended learning: A Q method analysis. Educational Sciences: Theory \& Practice, 18(2), 427-446 Retrieved from https://eric.ed.gov/?id=EJ1201838.

Lanier, M. M. (2006). Academic integrity and distance learning. Journal of Criminal Justice Education, 17(2), 244-261 Retrieved from https://www.tandfonline.com/doi/abs/10.1080/10511250600866166. 
Lei, S. A., \& Gupta, R. K. (2010). College distance education courses: Evaluating benefits and costs from institutional, faculty and students' perspectives. Education, 130(4), 616-631 Retrieved from https://www.questia.com/library/journal/1G1-2275 97132/college-distance-education-courses-evaluating-benefits.

Mahlangu, V. P. (2018). The good, the bad, and the ugly of distance learning in higher education. In M. Sinecen (Ed.), Trends in E-learning. https://doi.org/10.5772/intechopen.75702.

Ministry of Education and Science of Ukraine. (2017). Програма курсу "Інформатика" для 5-9 класів загальноосвітніх навчальних закладів [Program of the Course "Informatics" for Grades 5-9 of Secondary Schools]. Retrieved February 24 2020, from https://mon.gov.ua/storage/app/media/zagalna serednya/programy-5-9-klas/onovlennya-12-2017/programainformatika-5-9-traven-2015.pdf

Morris, P. D., \& Clark, L. M. (2018). Using NSSE data to analyze levels of engagement of distance learners. Quarterly Review of Distance Education, 19(2), 1-13 Retrieved from https://www.questia.com/library/journal/1P4-2166326369/using-nsse-datato-analyze-levels-of-engagement-of.

Nakamura, M. (2017). The state of distance education in Japan. Quarterly Review of Distance Education, 18(3), 75-87.

Peck, L., Stefaniak, J. E., \& Shah, S. J. (2018). The correlation of self-regulation and motivation with retention and attrition in distance education. Quarterly Review of Distance Education, 19(3), 1-16.

Perraton, H. (2008). Open and distance learning in the developing world. New York: Routledge.

Piletic, P. (2018). Lower costs are making more students prefer online education. Retrieved February 11, 2020, from eLearning industry website: https://elearningindustry.com/students-prefer-online-education-lower-costs-making

PORDATA - Base de Dados Portugal Contemporâneo. (2017). Indivíduos com 16 e mais anos que utilizam computador e Internet. Retrieved January 19, 2020, from Ciência, Tecnologia e Sociedade da Informação website: https://www.pordata. pt/DB/Portugal/Ambiente+de+Consulta/Tabela

Robinson, C. C., \& Hullinger, H. (2008). New benchmarks in higher education: Student engagement in online learning. Journal of Education for Business, 84(2), 101-109 Retrieved from https://www.tandfonline.com/doi/abs/10.3200/JOEB.84.2.101-109.

Sadykova, G., \& Dautermann, J. (2009). Crossing cultures and borders in international online distance higher education. Journal of Asynchronous Learning Network, 13(2), 89-114. https://doi.org/10.24059/olj.v13i2.1670.

Seok, S., DaCosta, B., Kinsell, C., \& Tung, C. K. (2010b). Comparison of instructor' and students' perceptions of the effectiveness of online courses. Quarterly Review of Distance Education, 11(1), 25.

Seok, S., DaCosta, R., Kinsell, C., \& Tung, C. (2010a). Comparison of instructors' and students' perceptions of the effectiveness of online courses. The Quarterly Review of Distance Education, 12(1), 25-36 Retrieved from http://online.nuc.edu/ctl_en/ wp-content/uploads/2015/08/Online-education-effectiviness.pdf.

Sharov, S., Liapunova, V., \& Sharova, T. (2019). Analysis of the opportunities of the prometheus platform for the professional development of future teachers. TEM Journal, 8(4), 1469-1476. https://doi.org/10.18421/TEM84-52.

Strutynska, O., \& Umryk, M. (2016). The use of MOOCs for training of the future computer science teachers in Ukraine. In S. N. for U. of S. in K. Editor Eugenia Smyrnova-Trybulska (Ed.), E-learning \& Lifelong Learning. Monograph. (pp. 297-320). Katowice-Cieszyn.

Summers, J. J., Waigandt, A., \& Whittaker, T. A. (2005). A comparison of student achievement and satisfaction in an online versus a traditional face-to-face statistics class. Innovative Higher Education, 29(3), 233-250 Retrieved from https://link. springer.com/article/10.1007/s10755-005-1938-x

The Cabinet of Ministers of Ukraine. (2019). Презентація першого в Україні дослідження з цифрової грамотності населення [Presentation of the First Digital Literacy Survey in Ukraine]. Retrieved from https://www.youtube.com/ watch?v=t3ghLyjzqLM\&feature=youtu.be

The State Statistics Service of Ukraine. (2019). Communication Subscribers as of January 1. Retrieved February 24, 2020, from http://www.ukrstat.gov.ua/operativ/operativ2019/zv/az/az_e/az0119_e.htm

Tseng, H., \& Walsh Jr., E. J. (2016). Blended versus traditional course delivery: Comparing students' motivation, learning outcomes, and preferences. The Quarterly Review of Distance Education, 17(1), 43-52.

United Arab Emirates Ministry of Education. (2016). Higher Education emphasizes the need to check accredited e-learning universities list. Retrieved September 16, 2019, from https://www.moe.gov.ae/En/MediaCenter/archive/mohesr/news/ Pages/Higher-Education-emphasizes-the-need-to-check-accredited-e-learning-universities-list.aspx

Venter, K. (2003). Coping with isolation: The role of culture in adult distance learners' use of surrogates. Open Learning, 18(3), 271-287 Retrieved from https://www.tandfonline.com/doi/abs/10.1080/0268051032000131035.

Watts, L. (2016). Synchronous and asynchronous communication in distance learning: A review of the literature. Quarterly Review of Distance Education, 17(1), 23-32.

Zawacki-Richter, O., \& Naidu, S. (2016). Mapping research trends from 35 years of publications in distance education. Distance Education, 37(3), 245-269. https://doi.org/10.1080/01587919.2016.1185079.

Zuhairi, A., Wahyono, E., \& Suratinah, S. (2006). The historical context, current development, and future challenges of distance education in Indonesia. Quarterly Review of Distance Education, 7(1), 95-101 Retrieved from https://www.questia.com/ library/journal/1P3-1040201321/the-historical-context-current-development-and-future.

\section{Publisher's Note}

Springer Nature remains neutral with regard to jurisdictional claims in published maps and institutional affiliations. 